\title{
Chemical characteristics and organoleptic of gluten-free toddler biscuits from mung bean flour, modified cassava flour and flaxseed
}

\author{
${ }^{1}$ Amalia, L., ${ }^{2,}$ Setiarto, R.H.B., ${ }^{1}$ Nuraulia, G.W. and ${ }^{3}$ Mariyani, N. \\ ${ }^{1}$ Department of Food Technology and Nutrition, Faculty of Halal Food Science, Djuanda University, Bogor, \\ Jl. Tol Jagorawi No. 1, Post Box 35 Ciawi, Bogor 16720 \\ ${ }^{2}$ Research Center for Biology, Indonesian Institute of Sciences (LIPI) Main Street Jakarta-Bogor Km 46, \\ Cibinong Science Center, Cibinong, Bogor, 16911 West Java, Indonesia \\ ${ }^{3}$ College of Vocational Studies IPB University, Jl. Kumbang No. 14, Bogor Tengah, Bogor 16128
}

\begin{abstract}
Article history:
Received: 21 October 2020

Received in revised form: 5

December 2020

Accepted: 16 February 2021

Available Online: 20 June

2021
\end{abstract}

Keywords:

Gluten-free biscuit toddler,

Mung bean flour,

Mocaf,

Flaxseed,

Omega-3

DOI:

https://doi.org/10.26656/fr.2017.5(3).600

\begin{abstract}
Biscuits a type of snack that is favoured by almost all groups of people especially children. This research was conducted to produce omega-3 gluten-free biscuits for toddlers. This study used a completely randomized design (CRD) one factor with 3 levels of treatment. The factor was the ratio of modified cassava flour (mocaf) and flaxseed with concentrations of $24 \%: 1 \%, 22 \%: 3 \%$, and $20 \%$ : $5 \%$. Product analysis included organoleptic tests (sensory and hedonic quality) by semi-trained panellists, chemical tests (proximate, crude fiber, omega-3) and total energy content. Gluten-free toddler biscuits with the addition of mocaf and flaxseed 20\%: 5\% were selected products from the results of this study. The product had a sensory quality that was dark brown, slightly scented with a pleasant aroma, soft texture, sweet taste and overall, very good. The hedonic test results produced an average value of 5 , which is rather like all parameters. The resulting nutritional content $(\mathrm{w} / \mathrm{w})$ on a wet basis $(\mathrm{wb})$ : water content $3.79 \%$, ash $1.71 \%$, protein $7.89 \%$, fat $24.61 \%$, carbohydrate $62.00 \%$, with a total energy of $501.05 \mathrm{kcal} / 100 \mathrm{~g}$, crude fibre $1.39 \%$, and the highest omega-3 content of $818.45 \mathrm{mg} / 100 \mathrm{~g}$. Consumption of three biscuits for toddlers $(20 \mathrm{~g})$ can meet the energy intake of $6.5 \%$ Recommended Dietary Allowance (RDA), 4.5\% RDA protein, 5.3\% RDA carbohydrate, 9.1\% RDA fat, and omega-3 at $17.8 \%$ RDA per day. The produced toddler biscuits had a protein content of $22.5 \%$ RDA per $100 \mathrm{~g}$, so they could be claimed as a high protein source.
\end{abstract}

\section{Introduction}

Food allergy is an immunological response to a specific food antigen. Foodstuffs that are most at risk of causing allergies are cow's milk, goat's milk, eggs, peanuts, sea fish, soybeans and wheat (Hussain et al., 2012; Aini and Wirawani, 2013). Biscuits for toddlers are processed foods made from wheat flour, vegetable fat with or without milk fat (Hussain et al., 2006). Wheat, oats, and barley have glutenin and gliadin proteins that can form gluten (Sudha et al., 2007). Individuals who are allergic to gluten such as people with gluten intolerance and ASD (Autism Spectrum Disorder) must avoid gluten so that it does prevent negative impacts on the body (Aini and Wirawani, 2013; Yustisia, 2013). Currently, the products of mocaf (modified cassava flour) have been developed. Mocaf is a product derived from cassava flour that uses the principle of biological modification using lactic acid bacterial fermentation
(Ratnawati et al., 2020). Mocaf does not contain glutenin and gliadin proteins that produce gluten such as wheat flour, so the resulting biscuits have a very low protein content and gluten-free (Hidayati, 2015; Lopulalan et al., 2016).

Mung beans have a fairly high protein content of $22 \%$ and contain important mineral sources, namely calcium and phosphorus (Habibullah and Shah, 2007). The carbohydrate content of mung beans is easy to digest, making it suitable for use as food for infants and adults (Ekafitri and Isworo, 2014). The addition of mung bean flour can increase the protein content in plant-based biscuits. Flaxseeds are a source of omega-3 compounds of vegetable origin (Oomah, 2001). In addition to containing omega-3 fatty acids, flaxseed contains protein, dietary fibre, and lignin (Ganorkar and Jain, 2013). This research is aimed to produce plant-based biscuits that are gluten-free and contain omega-3 which 
is good for toddlers. In addition, this study is also aimed to determine the effect of the ratio of mocaf and flaxseed on chemical content (proximate and omega-3) and organoleptic characteristics (sensory and hedonic quality) of gluten-free toddler biscuits produced and to determine the nutritional content of selected gluten-free toddler biscuits accordingly RDA (Recommended Dietary Allowance) from Regulation Ministry of Health Republic of Indonesia (2013).

\section{Materials and methods}

\subsection{Material}

The main ingredients used in the production of gluten-free toddler biscuits were mung bean flour, mocaf, tapioca, sugar, palm oil, water, ground flaxseed and vanilla powder. The materials used in the analysis was selenium, concentrated $\mathrm{H}_{2} \mathrm{SO}_{4}$, distilled water, $4 \%$ boric acid, $0.2 \mathrm{~N} \mathrm{HCl}, 1.25 \% \mathrm{H}_{2} \mathrm{SO}_{4}, 3.25 \% \mathrm{NaOH}, 95 \%$ alcohol, $0.5 \mathrm{M} \mathrm{KOH}, 20 \% \mathrm{BF}_{3}$, methanol, hexane, $\mathrm{N}_{2}$ gas, saturated $\mathrm{NaCl}$ solution, and anhydrous $\mathrm{Na}_{2} \mathrm{SO}_{4}$

\subsection{Gluten-free toddler biscuits production}

The ingredients to produce the gluten-free toddler biscuits was sieved with 40-mesh sieve. The mixing of the ingredients was carried out in two stages. In the first stage of mixing, mocaf and flaxseed flour with a formula ratio of (A1) 24\%: 1\%, (A2) 22\%: 3\%, (A3) 20\%: 5\% were mixed into other dry ingredients such as mung bean flour, sugar, tapioca, and vanilla powder. The formulation of gluten-free toddler biscuits could have been seen in Table 1 .

Table 1. Gluten-free toddler biscuit formulation

\begin{tabular}{lccc}
\hline \multirow{2}{*}{ Dry materials } & \multicolumn{3}{c}{ Content } \\
\cline { 2 - 4 } & A1 & A2 & A3 \\
\hline Mocaf (\%) & 24 & 22 & 20 \\
Flaxseed giling (\%) & 1 & 3 & 5 \\
Mung bean flour (\%) & 35 & 35 & 35 \\
Tapioca (\%) & 16 & 16 & 16 \\
Sugar (\%) & 23 & 23 & 23 \\
Vanilla powder (\%) & 1 & 1 & 1 \\
Total (\%) & 100 & 100 & 100 \\
Wet materials & & & \\
Palm oil (\%) & 27 & 27 & 27 \\
Water (\%) & 12 & 12 & 12 \\
\hline
\end{tabular}

The second mixing process was carried out until it was even and smooths with the addition of palm oil as much as $27 \%$ and water as much as $13 \%$ of the total dry matter. Biscuits were made into sheets with a thickness of $0.4 \mathrm{~cm}$ and printed in a circle $(\varnothing=5 \mathrm{~cm})$ (Figure 1). Biscuits were baked in an electric oven at $140^{\circ} \mathrm{C}$ for 35 mins.

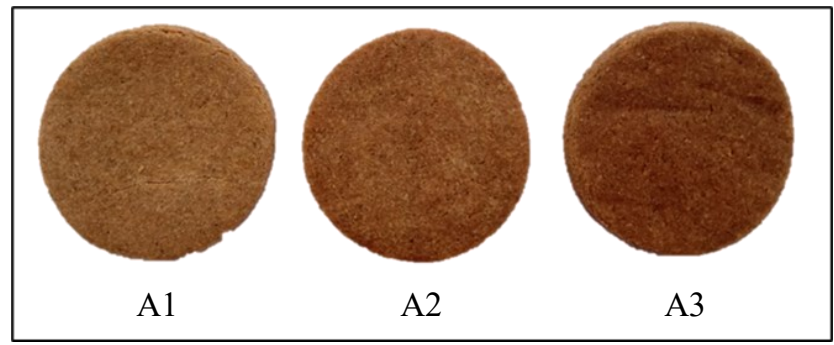

Figure 1. Gluten-free toddler biscuits

\subsection{Product analysis}

The biscuits produced was tested using chemical tests and organoleptic tests (Figure 1). Chemical tests using a wet basis (wb) include moisture content (BSN, 2011), ash (AOAC, 2000), protein (AOAC, 2000), fat (AOAC, 2000), calculation of carbohydrates by difference (BSN, 1992), crude fibre (BSN, 1992). Chemical test results were used to calculate total energy (Almatsier, 2001). Organoleptic test with sensory quality test (line scale $10 \mathrm{~cm}$ ) and hedonic test (scale 1-7) with colour, aroma, texture, taste and overall parameters carried out by 30 semi-trained panellists. The selected product was determined based on the best chemical and organoleptic test results.

2.4 Analysis of omega-3 fatty acids (alpha-linolenic acid (ALA), eicosapentaenoic acid (EPA), docosahexaenoic acid (DHA)

For the analysis of omega 3 fatty acids, the fat was trans esterified by adding a $15 \%$ solution of boron tri fluoride $\left(\mathrm{BF}_{3}\right)$ in methanol and heated at $60^{\circ} \mathrm{c}$ for 30 mins. Then the solution was cooled and added with nhexane, shaken so that all methyl esters was dissolved in $\mathrm{n}$-hexane. The mixture was left to stood for \pm 10 mins until two layers was formed. The top layer in the form of methyl ester in n-hexane was separated from the bottom layer in the form of unestered methanol and injected into gas chromatography. The retention time of the components expected (ALA, EPA and DHA) of the obtained chromatogram was determined by comparing with the retention time of ALA, EPA and DHA standards that had previously been made in the chromatogram (Hadipranoto, 2005).

\subsection{Data analysis}

The statistical data analysis used in this studied was using Microsoft Excel and the SPSS 20 program. The statistical test used for the chemical test results and the sensory quality test was the variance test (ANOVA), if the $p$ value $<0.05$ (significant effect), then the Duncan Multiple Range Test (DMRT) continued test with a confidence levelled of $95 \%(\alpha=0.05)$. The statistical test on the hedonic test results was the Kruskal Wallis test, if 
the $\mathrm{p}$ value was $<0.05$ (significant effect), then the further test used the Mann-Whitney Test with a confidence levelled of $95 \%(\alpha=0.05)$ to determine which treatment was different.

\section{Results and discussion}

\subsection{Chemical test of gluten-free toddler biscuits}

The product was tested for proximate, crude fibre and omega-3 for two times and the total energy was calculated. The average data for chemical test results can be seen in Table 2. The formulation A3 Gluten-free Toddler Biscuits (Mocaf 20\%: Flaxseed 5\%) produces the highest omega-3 content $(818.45 \mathrm{mg} / 100 \mathrm{~g})$, the highest crude fibre content $(1.39 \%)$, the highest fat content $(28.25 \%)$, the highest protein content $(7.89 \%)$ and the highest total energy (519.25 kcal/100 g) compared to formulations A1 (Mocaf 24\%: Flaxseed $1 \%$ ) and A2 (Mocaf 22\%: Flaxseed 3\%). A3 formulation Gluten-free toddler biscuits provide higher nutritional value and benefit human health than $\mathrm{A} 1$ and $\mathrm{A} 2$ formulations. It was also able to meet the RDA that has been determined by the Regulation of the Ministry of Health of the Republic of Indonesia (2013). Formulation A1 (Mocaf 24\%: Flaxseed 1\%) produced the highest carbohydrate content (64.98\%) compared to formulations A2 and A3. However, the high carbohydrate content does not really contribute to producing high total energy because the energy value of $1 \mathrm{~g}$ of carbohydrates is converted to $4.1 \mathrm{kcal}$, while $1 \mathrm{~g}$ of fat is converted to 9.1 kcal.

Table 2. Chemical composition of Gluten-free Toddler Biscuits

\begin{tabular}{lccc}
\hline Parameter & A1 & A2 & A3 \\
\hline Moisture content (\%) & $3.70^{\mathrm{a}}$ & $3.6^{\mathrm{a}}$ & $3.79^{\mathrm{a}}$ \\
Ash content (\%) & $1.72^{\mathrm{a}}$ & $1.52^{\mathrm{a}}$ & $1.71^{\mathrm{a}}$ \\
Protein content (\%) & $7.13^{\mathrm{a}}$ & $7.43^{\mathrm{b}}$ & $7.89^{\mathrm{c}}$ \\
Fat content (\%) & $22.48^{\mathrm{a}}$ & $24.35^{\mathrm{b}}$ & $28.25^{\mathrm{c}}$ \\
Carbohydrate content (\%) & $64.98^{\mathrm{c}}$ & $63.02^{\mathrm{b}}$ & $58.35^{\mathrm{a}}$ \\
Total energy (kcal/100 g) & $490.77^{\mathrm{a}}$ & $500.94^{\mathrm{b}}$ & $519.25^{\mathrm{c}}$ \\
Crude fibre (\%) & $0.55^{\mathrm{a}}$ & $0.94^{\mathrm{a}}$ & $1.39^{\mathrm{b}}$ \\
Omega-3 (mg/100 g) & $218.75^{\mathrm{a}}$ & $472.60^{\mathrm{b}}$ & $818.45^{\mathrm{c}}$ \\
\hline
\end{tabular}

Values with different superscript in a row are significantly different at $\alpha=0.05$

\subsubsection{Moisture content}

The moisture content of toddler biscuits was tested using the gravimetric method. The results of the analysis of moisture content of toddler biscuits were A1 (3.70\%), A2 (3.68\%), and A3 (3.79\%). The moisture content of the biscuits produced has met the quality standards of SNI 01-2973-2011 biscuits (BSN, 2011), which is a maximum of $5 \%$. Based on the results of analysis of variance, it showed that the ratio of mocaf and flaxseed had no significant effect on the water content of toddler biscuits $(\mathrm{p}>0.05)$. This is in accordance with Masoodi and Bashir (2012), the biscuit products fortified with flaxseed did not experience a significant change in water content and were not significantly different between treatments. The resulting moisture content of the product was $6.07 \%, 6.30 \%$ and $6.63 \%$. Mocaf and flaxseed have a low WBC (water binding capacity) capacity during the production process of gluten-free toddler biscuits. This indicates that the moisture content of gluten-free toddler biscuits is not significantly different for formulations A1, $\mathrm{A} 2$, and $\mathrm{A} 3$.

\subsubsection{Ash content}

The ash content of toddler biscuits was tested using the gravimetric method. The results of the analysis of the ash content of toddler biscuits were A1 (1.72\%), A2 $(1.52 \%)$, and $\mathrm{A} 3(1.71 \%)$. Based on the results of analysis of variance, it showed that the ratio of mocaf and flaxseed had no significant effect on the ash content of toddler biscuits $(\mathrm{p}>0.05)$. This can be caused by the not large percentage range of mocaf and flaxseed additions between the three samples. The ash content of gluten-free toddler biscuits is influenced by the ash content of the constituent ingredients. Mung bean flour is the main ingredient for gluten-free toddler biscuits. Habibullah and Shah (2007) stated that the proximate test results of mung bean flour from two local mung bean varieties had an ash content of 3.0-3.9\%. Lopulalan et al. (2016) reported that the ash content of the local Sangkola variety mocaf flour produced was $0.17-0.74 \%$, as well as the ash content of flaxseed according to study by Bernacchia et al. (2014) of 3.4\%.

\subsubsection{Protein content}

The results of the analysis of the average protein content of toddler biscuits were A1 (7.13\%), A2 $(7.43 \%)$, and $\mathrm{A} 3(7.89 \%)$. The protein content of the biscuits produced meets the quality standards of SNI 012973-2011 biscuits (BSN, 2011), which is a minimum of $5 \%$. Based on the results of analysis of variance, it showed that the ratio of mocaf and flaxseed had a significant effect on the protein content of toddler biscuits $(\mathrm{p}<0.05)$. This is in accordance with Masoodi and Bashir (2012), biscuit products fortified with flaxseed have increased protein levels. The protein content of wheat flour control biscuits without the addition of flaxseed was $8.74 \%$ and biscuits with a ratio of wheat flour and flaxseed $3: 1$ to $10.53 \%$. The protein content of toddler biscuits is influenced by the protein content of the constituent ingredients. Ekafitri and Isworo (2014) reported that the proximate test results of 
mung bean flour $(23.25 \%)$. The results of research by Russo and Reggiani (2016) reported that of the seven varieties of flaxseed studied, they had protein levels of $33-37 \%$. Flaxseed has high protein content, so the fortification of adding flaxseed can significantly increase the protein content of gluten-free toddler biscuits.

\subsubsection{Fat content}

The results of the analysis of the average fat content of toddler biscuits were A1 (22.48\%), A2 (24.35\%), and A3 $(28.25 \%)$. The results of the analysis of variance showed that the ratio of mocaf and flaxseed had a significant effect on the fat content of toddler biscuits $(p<0.05)$. From the results of Duncan's further test of fat content, it can be seen that A1, A2 and A3 are significantly different. Increasing levels of flaxseed and lower levels of mocaf, the fat content of toddler biscuits will increase. This is consistent with research by Masoodi and Bashir (2012), biscuit products fortified with flaxseed have increased levels of fat. The fat content of wheat flour control biscuits without the addition of flaxseed was $4.04 \%$ and biscuits with a ratio of wheat flour and flaxseed $3: 1$ to $11.08 \%$. The test results of the proximate flaxseed used as fortification showed a fat content of $41.63 \%$. Flaxseed has a high fat content, so the fortification of adding flaxseed can significantly increase the fat content of gluten-free toddler biscuits.

\subsubsection{Carbohydrate content}

The results of the analysis of carbohydrate content by difference of the average biscuits for toddlers are A1 (64.98\%), A2 (63.02\%), and A3 (58.35\%). The results of the analysis of variance showed that the ratio of mocaf and flaxseed had a significant effect on the carbohydrate content of toddler biscuits $(p<0.05)$. From the results of Duncan's continued test of carbohydrate content, it can be seen that A1, A2, and A3 are significantly different even though the differences in the three are only slightly. This is in accordance with the study by Masoodi and Bashir (2012) that biscuit products fortified with flaxseed experience a decrease in carbohydrate levels. The carbohydrate content of wheat flour control biscuits without the addition of flaxseed was $80.22 \%$ and biscuits with a ratio of flour and flaxseed 3: 1 to $69.70 \%$. Flaxseed contains low carbohydrates (sugar and starch), only $1 \mathrm{~g}$ per $100 \mathrm{~g}$ of flaxseed (Bernacchia et al., 2014). The carbohydrate content in the resulting mocaf flour is 80.09-82.68\% (Lopulalan et al., 2016). The carbohydrate content of biscuit products is also influenced by the content of other macronutrients such as water, ash, fat and protein. The higher the levels of other macronutrients, the lower the carbohydrate level.

\subsubsection{Total energy}

The results of the analysis of the estimated total energy estimates for the average toddler biscuits per 100 $\mathrm{g}$ are A1 (490.77 kcal), A2 (500.94 kcal), and A3 $(519.25 \mathrm{kcal})$. The results of the analysis of variance showed that the ratio of mocaf and flaxseed had a significant effect on the total energy of toddler biscuits per $100 \mathrm{~g} \quad(\mathrm{p}<0.05)$. From the results of Duncan's continued test of total energy, it can be seen that A1, A2, and $\mathrm{A} 3$ are significantly different. Flaxseed has a high fat and protein content which can contribute to producing energy (calory), so the fortification of adding flaxseed can significantly increase the total energy of gluten-free toddler biscuits.

\subsubsection{Crude fibre}

The results of the analysis of crude fibre content for toddler biscuits were A1 (0.55\%), A2 (0.94\%), and A3 $(1.39 \%)$. Based on the results of analysis of variance, it showed that the ratio of mocaf and flaxseed had a significant effect on crude fibre content of toddler biscuits $(p<0.05)$. From the results of Duncan's continued test, crude fibre content, it can be seen that the three samples are significantly different. The higher the flaxseed level and the lower the mocaf content, the higher the crude fibre content of toddler biscuits. Crude fibre is obtained from the materials used. Habibullah et al. (2007), reported that the proximate test results of mung bean flour from two local mung bean varieties produced crude fibre of $6.8-7.1 \%$. Mocaf contains crude fibre content of 12\% (Lopulalan et al., 2016). Meanwhile, flaxseed contains 30\% dietary fibre (Daun et al., 2003). Flaxseed has high crude fibre content, so the fortification of adding flaxseed can significantly increase the crude fibre content of gluten-free toddler biscuits.

\subsubsection{Omega-3 content}

The peak chromatogram results showed that the sample contained palmitic acid (16:0), stearic acid (18:0), oleic acid (18:1), linoleic acid (18:2), and linolenic acid (18:3). Palmitic acid and stearic acids showed the highest yield because they were fatty acids derived from palm oil. This research is devoted to analysing the content of omega-3 (ALA (18:3), EPA (20:5) and DHA (22:6). The peak chromatogram results can be seen in Figure 2 (a), (b), and (c).

The RT (retention time) omega-3s identified in the GC-MS chromatogram were ALA (alpha-linolenic acid) at 13.429 mins, and EPA (eicosapentaenoic acid) compounds at 17.349 mins. Meanwhile the omega-3 DHA compound (docosahexaenoic acid) has not been identified. The table of the results of gas chromatography identification and the fatty acid content of gluten-free 
(a)

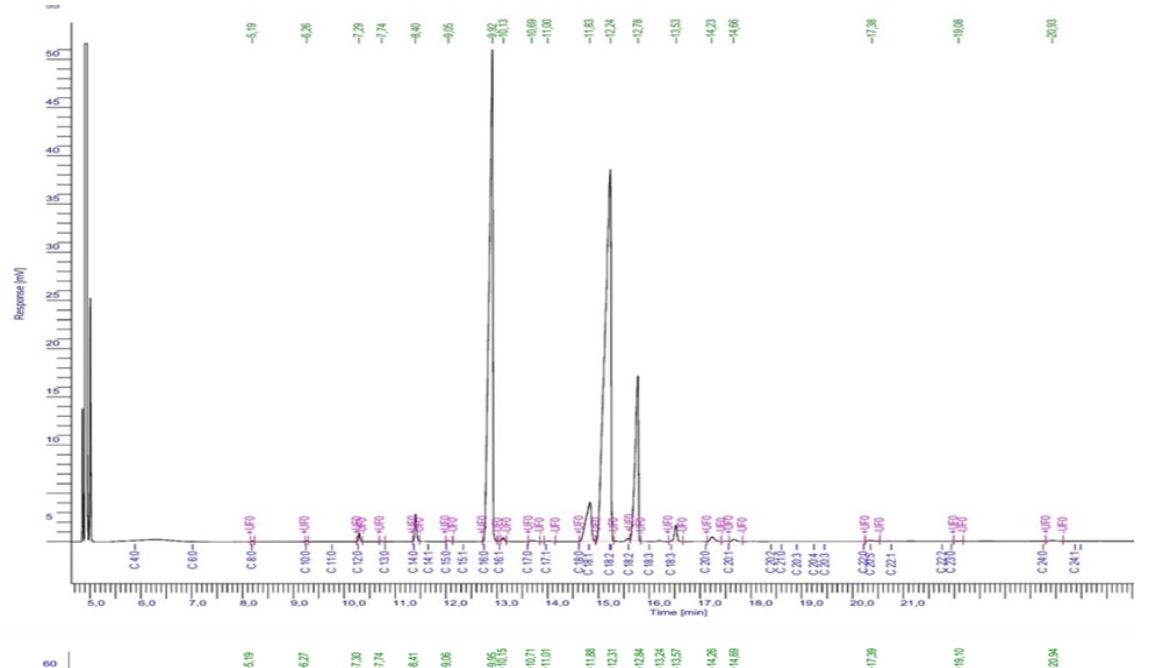

(b)

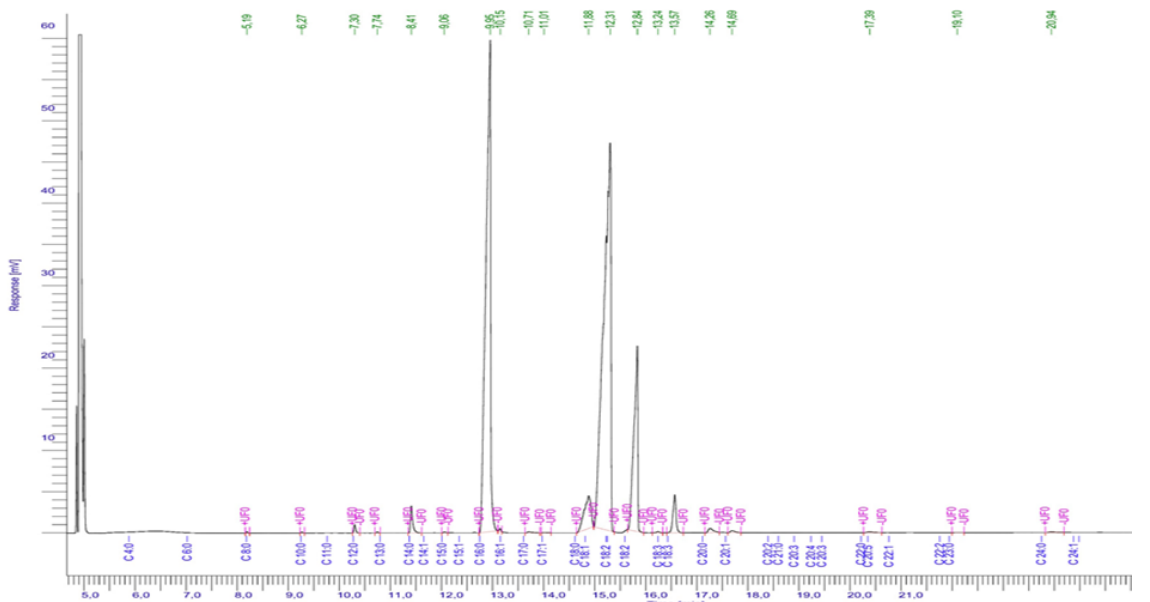

(c)

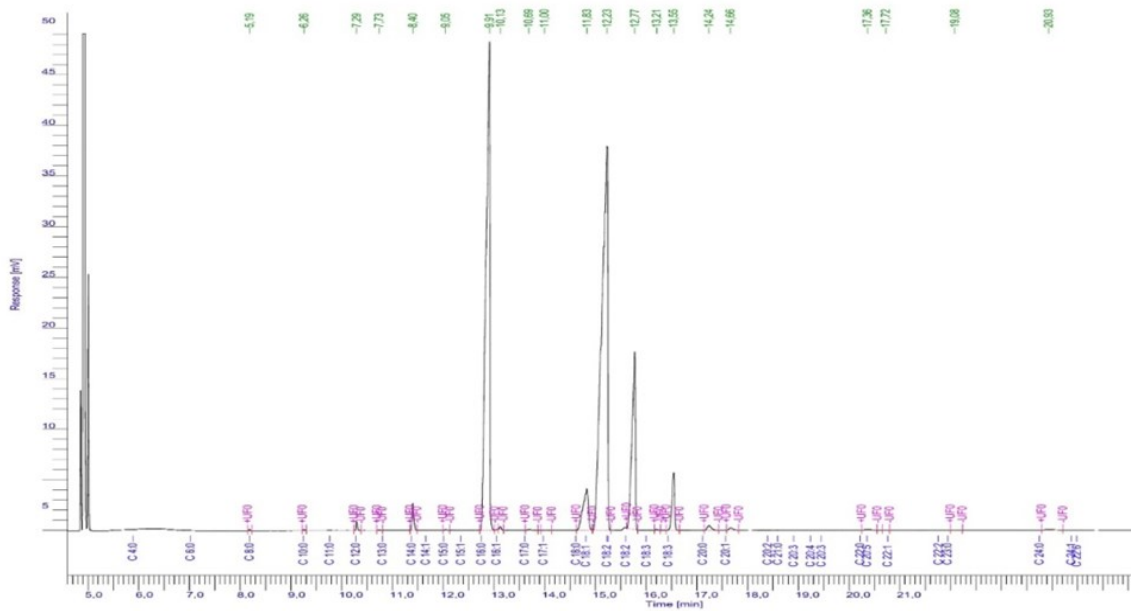

Figure 2. The peak chromatogram GC-MS for toddler biscuits (a) A1, (b) A2, (c) A3

toddler biscuits produced can be seen in Figure 3.

The results of the analysis of the omega-3 levels of gluten-free toddler biscuits were A1 $(218.75 \mathrm{mg} / 100 \mathrm{~g})$, A2 $(472.60 \mathrm{mg} / 100 \mathrm{~g})$, and A3 $(818.45 \mathrm{mg} / 100 \mathrm{~g})$ (Figure 2). Based on the analysis of variance, it showed that the ratio of mocaf and flaxseed had a significant effect on the omega-3 levels of gluten-free toddler biscuits $(p<0.05)$. From the results of Duncan's continued test of omega-3 levels, it can be seen that the three samples were significantly different. Formulations with the addition of high amounts of flaxseed and reduced composition of mocaf can increase omega-3 levels of gluten-free toddler biscuits. Of all the lipids contained in

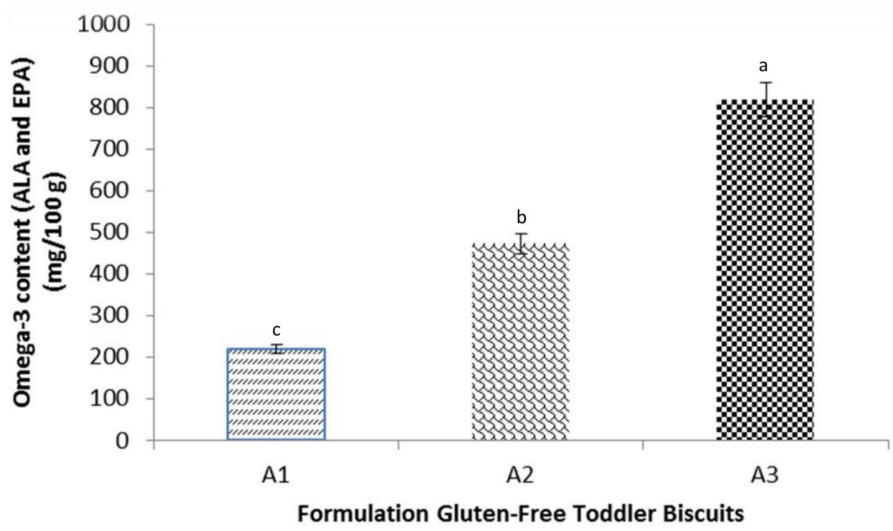

Figure 3. Omega-3 content (ALA and EPA) gluten-free toddler biscuits. Different letters on the bar chart are significantly different at 95\% confidence level, $(\alpha=5 \%)$ based on Duncan Multiple Range Test (DMRT).

(C) 2021 The Authors. Published by Rynnye Lyan Resources 
flaxseed (30\%), 53\% are $\alpha$-linolenic acid (ALA), 17\% linoleic acid (LA), 19\% oleic acid, 3\% stearic acid, and $5 \%$ palmitic acid (Simopoulos, 2002). This is in accordance with the research of Vadukapuram et al. (2014), ALA levels increased significantly with increased levels of flaxseed in extrudate snack products. The ALA level in the control product was $386 \mathrm{mg} / 100 \mathrm{~g}$ and after the addition of $5 \%$ flaxseed increased to 479 $\mathrm{mg} / 100 \mathrm{~g}$ ALA.

\subsection{Organoleptic evaluation of gluten-free toddler biscuits}

\subsubsection{Sensory evaluation quality}

The sensory quality test was carried out to determine the specific product characteristics according to the panellists for the biscuit products produced with a line scale of $10 \mathrm{~cm}$. Parameters of colour (light brown - dark brown), aroma (smells unpleasant - does not smell unpleasant), texture (solid/hard - crunchy/soft), taste (bitter - sweet), and overall (dislike - like). Panellists are students aged 19-23 years who are classified as semitrained panellists as many as 30 panellists. The results of the sensory quality test for toddler biscuits can be seen in Table 3. The A1 formulation of gluten-free toddler biscuits provides the preferred colour and aroma than the $\mathrm{A} 2$ and $\mathrm{A} 3$ formulations based on the results of sensory evaluation quality. The formulations A1, A2, and A3 gluten-free toddler biscuits did not have a significant effect on the texture, taste, and overall parameters based on the results of sensory evaluation quality.

Table 3. Sensory quality test results

\begin{tabular}{lccc}
\hline Parameter & A1 & A2 & A3 \\
\hline Colour & $5.33^{\mathrm{b}}$ & $3.89^{\mathrm{a}}$ & $3.61^{\mathrm{a}}$ \\
Aroma & $6.13^{\mathrm{b}}$ & $4.68^{\mathrm{a}}$ & $4.80^{\mathrm{a}}$ \\
Texture & $5.53^{\mathrm{a}}$ & $5.51^{\mathrm{a}}$ & $5.64^{\mathrm{a}}$ \\
Taste & $6.05^{\mathrm{a}}$ & $5.51^{\mathrm{a}}$ & $5.48^{\mathrm{a}}$ \\
Overall & $5.89^{\mathrm{a}}$ & $5.87^{\mathrm{a}}$ & $5.75^{\mathrm{a}}$ \\
\hline
\end{tabular}

Values with different superscript in a row are significantly different at $\alpha=0.05$

\subsubsection{Colour}

Based on the results of the sensory quality test for toddler biscuit colour parameters (dark brown - light brown), the average value is obtained in Table 3. The value of biscuit colour ranges from 3.61-5.33, which leads to light brown to dark brown. The results of analysis of variance (ANOVA) showed that the ratio of mocaf and flaxseed had a significant effect on the sensory quality of the resulting colour parameters $(p<0.05)$. Based on the results of Duncan's test, that the ratio of mocaf and flaxseed $\mathrm{A} 2$ and $\mathrm{A} 3$ was not significantly different, and both were significantly different to the sensory quality of the A1 biscuit colour parameters. In A1 the resulting colour leads to a light brown colour, while the A2 and A3 biscuits lead to a dark brown colour. This is in accordance with the research of Hussain et al. (2006), an increase in the intensity of dark colour on biscuits was observed due to the increased level of addition of flaxseed flour which could be caused by the dark brown colour of the flaxseed.

\subsubsection{Aroma}

Based on the results of the sensory quality test for toddler biscuit aroma parameters (smells unpleasant not smells unpleasant), the average value is obtained in Table 3, resulting in a biscuit aroma value ranging from 4.68-6.13 which leads from smelling unpleasant to no unpleasant smell. The results of analysis of variance (ANOVA) showed that the ratio of mocaf and flaxseed had a significant effect on the sensory quality of the aroma parameters produced $(p<0.05)$. Based on the results of Duncan's test, that the ratio of mocaf and flaxseed A1 was significantly different to the sensory quality of the A2 and A3 biscuit aroma parameters. In A1, the resulting aroma leads to no unpleasant aroma, while A2 and A3 biscuits lead to an unpleasant aroma. The unpleasant smell that is produced comes from flaxseed. Nutritional components in food such as protein, fat, and carbohydrates contribute to aroma formation.

\subsubsection{Texture}

Based on the results of the sensory quality test for toddler biscuit texture parameters (solid/hard - crunchy/ soft), the average value is obtained in Table 3, resulting in a biscuit texture value ranging from 5.51 to 5.64 which leads to a crispy/soft texture. The results of analysis of variance (ANOVA) showed that the ratio of mocaf and flaxseed had no significant effect on the sensory quality of the resulting texture parameters $(\mathrm{p}>$ 0.05). According to Masoodi and Bashir (2012), water content affects the texture of a food product. In the water content test, the results of the analysis of variance showed that the ratio of mocaf and flaxseed had no significant effect on the water content of toddler biscuits. Thus, the texture of toddler biscuits from the three comparisons of mocaf and flaxseed was not significantly different.

\subsubsection{Taste}

Based on the sensory quality test results of the toddler biscuit taste parameters (bitter - sweet), the average value is obtained in Table 3, resulting in a biscuit taste value ranging from 5.48 to 6.05 which leads to a sweet taste. The results of analysis of variance (ANOVA) showed that the ratio of mocaf and flaxseed had no significant effect on the sensory quality of the 
resulting taste parameters $(\mathrm{p}>0.05)$. The resulting sweetness comes from sugar. According to Davis (2013), yellow flaxseed has a sweet taste similar to nuts. According to Bernacchia et al. (2014), the brown and yellow flaxseed varieties did not have a significant difference with the taste parameters.

\subsubsection{Overall}

Based on the results of the sensory quality test for the overall parameters of toddler biscuits (not good very good), the average value is obtained in Table 3, resulting in an overall value of biscuits ranging from 5.75 to 5.89 which leads to an overall very delicious. The results of analysis of variance (ANOVA) showed that the ratio of mocaf and flaxseed had no significant effect on the overall sensory quality of the resulting parameters $(p>0.05)$.

\subsubsection{Hedonic evaluation}

The acceptance test by the panellists was 30 semitrained panellists. The assessment of the level of liking is based on the parameters of colour, taste, aroma, texture and overall, with a rating scale of 1-7 (scale 1: very dislikes, 2: dislikes, 3: slightly dislikes, 4: normal, 5: rather likes, $6:$ like, 7: really like). The results of the hedonic test for toddler biscuits can be seen in Table 4 . The results of the hedonic test carried out resulted in an average value of 5, which was somewhat favourable for all parameters. The A1 formulation of gluten-free toddler biscuits provides the preferred colour and aroma than the $\mathrm{A} 2$ and $\mathrm{A} 3$ formulations based on the results of the hedonic test. The formulations A1, A2, and A3 glutenfree toddler biscuits did not have a significant effect on the texture and taste parameters based on the results of the hedonic test.

Table 4. Hedonic evaluation results

\begin{tabular}{lccc}
\hline Parameter & $\mathrm{A} 1$ & $\mathrm{~A} 2$ & $\mathrm{~A} 3$ \\
\hline Colour & $6.02^{\mathrm{a}}$ & $5.75^{\mathrm{a}}$ & $5.40^{\mathrm{b}}$ \\
Aroma & $5.60^{\mathrm{a}}$ & $5.03^{\mathrm{b}}$ & $5.17^{\mathrm{b}}$ \\
Texture & $5.85^{\mathrm{a}}$ & $5.67^{\mathrm{a}}$ & $5.53^{\mathrm{a}}$ \\
Taste & $5.23^{\mathrm{a}}$ & $5.05^{\mathrm{a}}$ & $5.22^{\mathrm{a}}$ \\
Overall & $5.83^{\mathrm{a}}$ & $5.45^{\mathrm{b}}$ & $5.35^{\mathrm{b}}$ \\
\hline
\end{tabular}

Values with different superscript in a row are significantly different at $\alpha=0.05$

\subsubsection{Colour}

Based on the results of the hedonic test of colour parameters on toddler biscuits, the average value is obtained in Table 4, resulting in the hedonic value of the colour parameters of the biscuits ranging from 5.4 to 6.02, where the responses tend to be somewhat like to like. The results of Kruskal Wallis analysis showed that the ratio of mocaf and flaxseed had a significant effect on the level of preference for panellists in the resulting colour parameters $(p<0.05)$. Based on the results of the continued Mann-Whitney test, it was found that the panellists' preference for the colours of the three biscuits $\mathrm{A} 1, \mathrm{~A} 2$ and $\mathrm{A} 3$ was significantly different $(\mathrm{p}<0.05)$. In the sensory quality test, the colour of the A1 sample has a light brown colour, while A2 and A3 are somewhat preferred because the colour is towards dark brown. Colour is influenced by the ingredients of the biscuit. Dark brown pigment is obtained from cocoa flaxseed (Davis, 2013). The colour of the biscuits is also influenced by caramelization and Maillard's reaction during baking.

\subsubsection{Aroma}

Based on the results of the hedonic test of aroma parameters on toddler biscuits, the average value is obtained in Table 4, resulting in the hedonic value of the biscuit aroma parameters ranging from 5.03-5.60, which in response tend to be somewhat like. The results of Kruskal Wallis analysis showed that the ratio of mocaf and flaxseed had a significant effect on the level of preference for panellists in the resulting aroma parameters $(p<0.05)$. Based on the results of the MannWhitney test, it was found that the panellists' preference for the smell of A1 biscuits was significantly different from $\mathrm{A} 2$ and $\mathrm{A} 3(\mathrm{p}<0.05)$, but $\mathrm{A} 2$ was not significantly different from A3 $(p<0.05)$. The ratio of mocaf and flaxseed A1 was somewhat preferred for the aroma parameter with the highest mean value. In the sensory quality test, the aroma of sample A1 was not unpleasant, while A2 and A3 were somewhat preferred. The aroma of the product is produced from the majority of the main ingredients, namely yellow flaxseed flour or chocolate flaxseed (Davis, 2013).

\subsubsection{Texture}

Based on the hedonic test results of texture parameters on toddler biscuits, the average value is obtained in Table 4, resulting in hedonic values for the texture parameters of biscuits ranging from 5.53-5.85, which in response tend to be somewhat like. The results of Kruskal Wallis analysis showed that the ratio of mocaf and flaxseed had no significant effect on the level of preference for panellists in the resulting texture parameters $(p>0.05)$. The mocaf and flaxseed ratios $A 1$, $\mathrm{A} 2$ and $\mathrm{A} 3$ are somewhat preferred on texture parameters. In the sensory quality test, the textures of the samples A1, A2 and A3 were crispy and tender.

\subsubsection{Taste}

Based on the results of the hedonic test for the taste 
parameters of toddler biscuits, the average value was obtained in Table 4, resulting in the hedonic value of the taste parameters of the biscuits ranging from 5.05-5.23, which in response tended to be somewhat like. The results of the Kruskal Wallis analysis showed that the ratio of mocaf and flaxseed had no significant effect on the level of preference for panellists in the resulting taste parameters $(p>0.05)$. The mocaf and flaxseed ratios $A 1$, $\mathrm{A} 2$ and $\mathrm{A} 3$ are somewhat preferred in taste parameters because in the sensory quality test, the flavours of samples A1, A2 and A3 are in the direction of sweetness. The sweet taste comes from the sugar used.

\subsubsection{Overall}

Based on the results of the overall hedonic test on toddler biscuits, the average value is obtained in Table 4 , resulting in the hedonic value of the overall parameters of the biscuits ranging from 5.35 to 5.83 , which in response tend to be somewhat like. The results of the Kruskal Wallis analysis showed that the ratio of mocaf and flaxseed had a significant effect on the panellist's preference for the overall biscuits produced $(\mathrm{p}<0.05)$. Based on the results of the Mann-Whitney test conducted, it was found that the level of preference for the panellists to the overall of the $\mathrm{A} 1$ biscuits was significantly different from A2 and A3 $(p<0.05)$, but A2 was not significantly different from A3 $(p<0.05)$.

\subsection{Featured gluten-free toddler biscuits}

Determination of the selected product is carried out based on chemical characteristics and organoleptic tests. In the hedonic test, it is known that the panellists' liking average value for each parameter of toddler biscuits (Table 4) resulted in an average value that was not significantly different in the biscuit samples A1, A2 and A3 which were rather like. Based on the chemical characteristics (Table 2), the A3 biscuit sample (mocaf 20\%: flaxseed 5\%) had a higher nutrient content other than carbohydrates than samples A1 (mocaf 24\%: flaxseed $1 \%$ ) and A2 (mocaf 22\%: flaxseed 3\%). Sample A3 has a protein content of $7.89 \%, 28.25 \%$ fat, $58.35 \%$ carbohydrates, with a total energy content of 519.25 $\mathrm{kcal} / 100 \mathrm{~g}$ and a crude fibre content of $1.39 \%$. In addition, the aim of adding flaxseed is to produce toddler biscuits containing omega-3, sample A3 has the highest omega-3 content of $818.45 \mathrm{mg} / 100 \mathrm{~g}$. It can be concluded that toddler biscuits with the addition of mocaf and flaxseed 20\%: 5\% are the selected products from the results of this study.

Based on the RDA per day for toddlers using the 4 to 6 year age group according to Regulation Ministry of Health Republic of Indonesia (2013), the calorie needs of toddlers are $1600 \mathrm{kcal}$. One selected toddler biscuit with an average weight of $6.8 \mathrm{~g}$ contains $35 \mathrm{kcal}$. If in one meal a toddler consumes 3 biscuits $(20 \mathrm{~g})$, it can meet the energy intake of $6.5 \% \mathrm{RDA}, 4.5 \%$ RDA protein, $5.3 \%$ RDA carbohydrate, 9.1\% RDA fat, and omega-3 at $17.8 \%$ RDA per day. According to the BPOM (2016), a product can be claimed for its nutritional content as a protein source if it contains protein not less than $20 \%$ RDA per $100 \mathrm{~g}$ in solid form. The results of the analysis of selected toddler biscuits had a protein content of $4.5 \%$ RDA per $20 \mathrm{~g}$ or $22.5 \%$ RDA per $100 \mathrm{~g}$, so it could be claimed as a protein source.

\section{Conclusion}

Gluten-free toddler biscuits with the addition of mocaf and flaxseed 20\%: 5\% were selected products from the results of this study. The biscuits produced have sensory qualities, namely dark brown colour, slight unpleasant aroma, crunchy/soft texture, sweet taste and overall neutrality. The results of the hedonic test carried out resulted in an average value of 5 , which was somewhat favourable for all parameters. The selected product contains water content of $3.79 \%(\mathrm{wb})$, ash content of $1.71 \%(\mathrm{wb})$, protein content of $7.89 \%(\mathrm{wb})$, fat $28.25 \%(\mathrm{wb})$, carbohydrate of $58.35 \%$, with the total energy is $519.25 \mathrm{kcal} / 100 \mathrm{~g}$, crude fibre content is $1.39 \%$ and the highest omega- 3 content (ALA and EPA) is $818.45 \mathrm{mg} / 100 \mathrm{~g}$. Consumption of 3 biscuits for toddlers (20g) can meet the energy intake of $6.5 \%$ RDA, $4.5 \%$ RDA protein, 5.3\% RDA carbohydrate, 9.1\% RDA fat, and omega- 3 at $17.8 \%$ RDA per day. The selected toddler biscuits had a protein content of $22.5 \%$ RDA per $100 \mathrm{~g}$, so it could be claimed as a protein source.

\section{Conflict of interest}

The authors declare no conflict of interest.

\section{References}

Aini, N.Q. and Wirawani, Y. (2013). Contribution of MP -ASI biscuits substitution of arrowroot flour, soybean and yellow sweet potato to the adequacy of protein, vitamin A, calcium and zinc in infants. Journal of Nutrition College, 2(4), 458-466. https:// doi.org/10.14710/jnc.v2i4.3727

Almatsier, S. (2001). Basic Principles of Nutrition. Jakarta: PT Gramedia Pustaka Utama.

AOAC (Association of Official Analitycal Chemist). (2000). Official Method of Analysis of The Association of Official Analytical of Chemist. Virginia, USA: Association of Official Analytical Chemist Inc,

BPOM (Badan Pengawas Obat dan Makanan). (2016). Peraturan Kepala Badan Pengawas Obat dan 
Makanan Republik Indonesia Nomor 13 Tahun 2016 tentang Pengawasan Klaim pada Label dan Iklan Pangan Olahan. Indonesia: BPOM. [In Bahasa Indonesia].

BSN (Badan Standardisasi Nasional). (1992). SNI 2973:1992 tentang Mutu dan Cara Uji Biskuit. Jakarta: Badan Standardisasi Nasional. [In Bahasa Indonesia].

BSN (Badan Standardisasi Nasional). (2011). SNI 2973:2011 tentang Biskuit. Jakarta: Badan Standardisasi Nasional. [In Bahasa Indonesia].

Bernacchia, R., Preti, R. and Vinci, G. (2014). Chemical composition and health benefits of flaxseed. Austin Journal of Nutrition and Food Sciences, 2(8), 1045.

Davis, W. (2013). Wheat Belly Cook Book. New York (US): Rodale Inc.

Daun, J.K., Barthet, V.J., Chonick, T.L. and Duguid, S. (2003). Structure, compotition, and variety development of flaxseed. In Thompson, L.U. and Cunnane, S.C. (Eds). Flaxseed in Human Nutrition, Vol. 2, p. 1-40. USA: AOCS Press. https:// doi.org/10.1201/9781439831915.ch1

Ekafitri, R. and Isworo, R. (2014). Utilization of nuts as a raw material source of protein for emergency food. Jurnal Pangan, 23(3), 134-145.

Ganorkar, P.M. and Jain, R.K. (2013). Flaxseed - a nutrional punch. International Food Research Journal, 20(2), 519-525.

Habibullah, A.M. and Shah, H.U. (2007). Proximate and mineral composition of mung bean. Sarhad Journal Agricultural, 23(2), 463-466.

Hadipranoto, N. (2005). Study on The Thermal Stability of EPA and DHA in Mujahir (Oreochromis mossambicus) Fish Oil. Indonesian Journal of Chemistry, 5(2), 152 - 155. https://doi.org/10.22146/ ijc. 21823

Hidayati, L.N. (2015). Diversification of Rich Biscuit products based on mocaf flour (modified cassava flour). E-Jurnal Boga, 4(3), 20-29.

Hussain, S., Anjum, F.A., Butt, M.S. and Alamri, M.S. (2012). Development and Evaluation of Nutritionally Superior Baked Products Containing Flaxseed. Pakistan Journal of Nutrition, 11(2), 160-165. https://doi.org/10.3923/pjn.2012.160.165

Hussain, S., Anjum, F.A., Butt, M.S., Khan, M.I. and Asghar, A. (2006). Physical and Sensoric Attributes of Flaxseed Flour Supplemented Cookies. Turkish Journal of Biology, 30, 87-92.

Lopulalan, C.G., Mailoa, M. and Pelu, H. (2016). Chemical and Physical Analysis of Modified Cassava Flour (mocaf) (local variety Sangkola) from Waai village, Central Maluku. AGRITEKNO, Jurnal
Teknologi Pertanian, 5(1), 7-12. https:// doi.org/10.30598/jagritekno.2016.5.1.7

Masoodi, L. and Bashir, V.A. (2012). Fortification of biscuit with flaxseed: biscuit production and quality evaluation. Journal of Environmental Science, Toxicology and Food Technology, 1(5), 6-9. https:// doi.org/10.9790/2402-0150609

Oomah, B.D. (2001). Flaxseed as a functional food source. Journal of the Science of Food and Agriculture, 81(9), 889-894. https://doi.org/10.1002/ jsfa. 898

Ratnawati, L., Desnilasari, D., Kumalasari, R. and Surahman, D.N. (2020). Characterization of modified cassava flour (mocaf)-based biscuits substituted with soybean flour at varying concentrations and particle sizes. Food Research, 4 (3), 645-651. https://doi.org/10.26656/fr.2017.4 (3). 282

Regulation Ministry of Health Republic of Indonesia. (2013). Regulation Ministry of Health Number 75 Year 2013 about Recommended Dietary Allowance for The People of Indonesia.

Russo, R. and Reggiani, R. (2016). Evaluation of protein and antinutritional compounds content in meal from seven flax varieties. Journal of Global Agriculture and Ecology, 6(3), 182-188.

Simopoulos, A.P. (2002). Omega-3 fatty acids in inflammation and autoimmune diseases. Journal of the American College of Nutrition, 21(6), 495-505. https://doi.org/10.1080/07315724.2002.10719248

Sudha, M.L., Vetrimani, R. and Leelavathi, K. (2007). Influence of fibre from different cereals on the rheological characteristics of wheat flour dough and on biscuit quality. Food Chemistry, 100(4), 13651370.

https://doi.org/10.1016/ j.foodchem.2005.12.013

Vadukapuram, N., Hall, C., Tulbek, M. and Niehaus, M. (2014). Physicochemical properties of flaxseed fortified extruded bean snack. International Journal of Food Science, 2014, 478018. https:// doi.org/10.1155/2014/478018

Yustisia, R. (2013). The effect of adding eggs on protein, fibre, chewiness level and acceptance of gluten-free wet noodles made of composite flour (composite flour: mocaf flour: tapioca and corn-starch). Journal of Nutrition College, 2(4), 697-703. 